\title{
A Multifactorial GIS-Based Analytical Method to Determine the Quality of Urban Green Space and Water Bodies
}

\author{
Clemens Deilmann \\ Iris Lehmann \\ Martin Behnisch \\ Jörg Hennersdorf \\ Ulrich Schumacher
}

\author{
Clemens Deilmann, (c.deilmann@ioer.de) \\ Iris Lehmann, (i.lehmann@ioer.de) \\ Martin Behnisch, (m.behnisch@ioer.de) \\ Jörg Hennerdorf, (j.hennersdorf@ioer.de) \\ Ulrich Schumacher, (u.schumacher@ioer.de) \\ all Leibniz Institute of Ecological Urban and Regional Development Dresden
}

\begin{abstract}
The type, size, and spatial distribution of public green spaces and water bodies are key factors for the microclimatic quality of urban areas, particularly within densely built-up districts, where they influence the quality of life. The analytical method presented in this paper looks at entire cities in a GIS-based approach that identifies potential critical areas of the city (with regard to heat stress or the accessability of green spaces) and quantifies their size and location in relation to green space and water bodies. The advantage of this method is that analysing the urban environment can be largely automated by the use of available geo base data. This requires the application of algorithms from the field of landscape ecology to the urban environment.

The method is based on multifactorial evaluation. Comparisons between cities are made possible by extremum normalisation. Densely built-up areas as well as all green spaces and water bodies within settlements are quantified in the form of areal indicators. Thus the proximity of densely built-up areas to green space or water bodies is measured by the indicator "Euclidian distance." By correlating the resulting potential heat islands with population data from the 2011 National Census, it is possible to determine the likely number of residents affected.

The method presented, which has been tested on seven cities in Germany, is part of a wide-ranging investigation into urban densities aimed at improving efficiency and environmental quality.
\end{abstract}

Keywords: green spaces, comparative analysis, urban density, green area accessability, microclimatic quality, urban heat islands

\section{Introduction}

The method presented in this paper to determine the quality of urban green spaces and bodies of water as a key factor and impact parameter on the urban microclimate situation and the quality of life in cities is one part of a research project to investigate urban density in regard to efficiency and environmental quality (http://www.ioer.de/1/projekte/compactnessand-efficiency/). Urban density, efficiency and environmental quality are closely interrelated and indeed competing factors. On the one hand they represent efforts to reduce the consumption of urban open space through infill development and infrastructural efficiency; on the other they express the aim to develop green infrastructure in order to improve the quality of life and environmental quality. The general goal is to achieve high quality and an optimal use of land while minimising or indeed reducing the exploitation of resources. Urban structures can be read in two or three dimensions as built-up objects such as roads, buildings, etc. as well as "interstitial spaces" such as public squares, green spaces and bodies of water 
with their functions for local residents such as housing, places of work, education, relaxation, local services provision, etc. Such structures are closely related to various urban systems such as the volume of traffic in a city, the level of soil sealing, the amount of urban greenery, the consumption of material resources and energy, as well as the level of emissions and immissions. They can help to achieve a particular urban density with a high level of resource efficiency and environmental quality.

The focus of the method presented is on the structure of the urban environment. One important question to be answered was whether a medium-scale resolution of 1:20,000 would permit the observation and analysis of interrelated structural forms that are closely linked to environmental quality and the quality of life, to resource and energy efficiency, to the issue of mobility and urban diversity. Thus, if the outskirts of a settlement have an open, cleft structure (in the form of an outspread hand) then parts of the outlying landscape can penetrate into the city centre, offering urban residents a short path to the outskirts and to open space. Pursuing this example, a similar effect is provided by a so-called "green belt" within urban areas, generally running along former city fortifications (as seen in the cities of Soest, Cologne and Neubrandenburg) or as an outer green ring (for example in Hanover and Cologne). The accessibility of such green spaces can be determined to a certain extent from a bird's eye view using topographic methods. Such urban structures (e.g., green belts) revealed by GIS analysis can give an indication of the services or qualities of a particular city. Of course, such an investigation does not reveal what role planning paradigmas originally served as orientation for the development of urban structures. Due to the inherently low pace of adaptation in the urban environment, it cannot be assumed that new paradigmas of urban design can transform the cityscape in only a few years. For an indication of change we must look to new urban developments. Nonetheless, over the long term, it is possible to discern whether urban planning and legislation has in fact steered new construction and developments towards particular structural models.

To underpin the above: in the field of urban construction there is a continuous development of guiding visions, strategies and building legislation to help clarify social aims and indeed to achieve these aims. Clear traces of the impact of these aims can be detected in the structure of the end product "city". These aims change over time. Today, the vision of a sustainable city - compact, efficient, with many green spaces and a high quality of life underlies all activities in the field of urban planning. At the same time the city's structure continues to display the results of previous visions. Thus we find obvious traces of the vision of the car-friendly city. Various measures and indices allow the interaction between aim and form, currently regarded as vital, to be physiognomically identified and quantified, and thus described. The measures, indices and algorithms have been borrowed from structural research in the field of landscape ecology, modified and further refined for urban analysis. These indices are supplemented by spatial base parameters.

In this paper we concentrate on the aspect of environmental quality, in particular the microclimatic impact of green space and bodies of water and their structural characteristics within cities as well as the possibilities for detecting strengths and weaknesses by form analysis.

\section{Background}

In urban research, the built environment is often investigated in terms of its twodimensional elements, specifically sealed and unsealed areas as well as green space and water surfaces, together with its three-dimensional elements, namely buildings and vegetation, as well as their diverse spatial patterns. Finke (1993) has called urban open spaces the "providers of ecological functions". Open spaces provide a safe environment for wild plants and animals, help reduce levels of atmospheric and water-borne pollution, and last but not least, can play a 
decisive role in regulating the urban climate (Haase, 2001). A large number of case studies and scientific investigations have shown that one crucial ecosystem service of urban vegetation is its regulatory effect on the urban (miro-)climate (Bowler et al., 2010; Endlicher et al., 2008; Gill et al., 2007, 2009; Lafortezza et al., 2009; Lehmann et al 2014, Nohl 1993; Oke et al. 1989; Wilmers, 1990; Alexandri \& Jones, 2008). The type, size, and spatial distribution of public green spaces and water bodies are therefore key factors.

Hege et al. $(1998,1999)$ have confirmed the regulatory effect of parks and other urban green spaces in cooling adjacent buildings. Temperature measurements in Berlin's green spaces have confirmed a direct link between this heat-reducing capacity and the size of green spaces (Sukopp \& Wittig, 1998). A study of the climatic impact of green spaces in an entire city, in this case Manchester, has shown that the air temperature is determined by the proportion of green space within the built environment. Results show that a $10 \%$ increase in the proportion of green space can ensure that the temperature remains within the normal range even on hot summer days. In contrast, the extreme scenario of a $10 \%$ reduction in the proportion of green space in the city centre or in densely built-up areas can lead to an increase in ground temperatures of between $7{ }^{\circ} \mathrm{C}$ and $8.2^{\circ} \mathrm{C}$ (Gill et al., 2007: 127).

Green spaces and bodies of water within the urban environment provide cities with ecosystem services. They influence the basic provision of services as well as human health (Naturkapital Deutschland - TEEB DE, 2012). The form and spatial distribution of public green spaces and bodies of water, particularly in densely built-up areas, are key factors determining the ecological quality and the quality of life for local residents (Arlt et. al, 2005). The air temperature, humidity and indeed movement of air all depend on the size and structure of public green spaces, i.e., the share of total area as well as the spatial distribution of grassy areas and meadows, areas of shrubbery, hedges and trees. Furthermore, plants in public green spaces can help trap dust and thus improve air quality. Parks featuring a good balance of trees, grassy areas, shrubbery and hedges are able to reduce air temperatures in the afternoon and evening in neighbouring areas at a distance of 200 to $300 \mathrm{~m}$. In this way they help prevent heat stress in humans on hot summer days (Arlt et al., 2005; Mathey et al., 2011). Green spaces increase water evaporation and consequently humidity, thereby improving bioclimatic conditions. They are vital to many cities in view of this positive impact on air quality. In addition, they serve to counteract or weaken the negative repercussions of inner-city heat islands, which frequently arise on hot summer days in urban areas with highly dense structures and extensive soil sealing (Matzarakis, 2001). One study that applied the HIRVAC model to examine the relationship between the structure of urban vegetation (in terms of the specific green volume) and the temperature lowering effect in 57 different urban structures (so-called urban vegetation structure types) confirmed that, alongside forest structure types, the structure types of green spaces in the urban environment displayed the greatest temperature lowering capacity (Lehmann et al., 2014). The question of how the cooling effects obtained by a city or an urban district are influenced by having one large as opposed to many smaller green spaces was investigated using the HIRVAC-2D model (Goldberg \& Bernhofer, 2001) for a site of approx. 236 ha. One modelling scenario assumed a large centrally located green space, while a second scenario assumed the same total size of green space but uniformly distributed across many smaller areas of greenery. While both scenarios indicated a drop in the total temperature of the urban area under study, the cooling effect was greatest in the case of the large central green space. However, the advantage of the smaller, well distributed green spaces was that they are more quickly accessible from neighbouring residential areas and that other potentially positive border effects can come into play (Mathey et al., 2011).

Natural and artificial bodies of water also reduce the temperature in settlement areas. As the water surface is generally cooler than the surrounding air, this leads through evaporation, 
to the so-called "oasis effect." Measurements undertaken in Oberhausen by Kuttler et al. (2012) have shown that bodies of water and woodland areas help reduce the impact not only of heat stress but also spells of extreme cold. In this paper the authors concentrate on the regulatory services of green space and bodies of water, in particular their influence on the urban climate.

\section{Method}

The microclimatic impact on built-up settlement areas of public green spaces and bodies of water as well as outlying green space can be analysed using the complex variables "potential at-risk areas" as well as the indicators "Euclidean distance" and "affected population." The basis for the investigation is our own model and others previously developed, as well as field investigations.

The variable "potential at-risk areas" is the ratio of densely built-up areas $>1$ ha in the urban environment that do not lie near any green spaces and/or bodies of water. These should in fact be understood as synonymous with potential heat islands in cities, as heat islands can particularly arise in such densely built-up urban areas that are outside the zone of influence of inner-city green space and bodies of water. Such potential at-risk areas have a strong tendency towards higher temperatures than surrounding areas, an effect with major consequences on human health. "Euclidean distance" is the distance between densely built-up areas and public green spaces or bodies of water as well as the green urban surroundings. These surroundings are areas of farmland as well as large bodies of water and extensive woodland. The variable "affected population" translates the areas and building densities into the number of residents who live in such at-risk areas.

The base data for the investigation is ATKIS-Basis DLM. The model geometry is the total urban environment. This is derived from the ATKIS-Basis DLM-Geometry from the existing so-called "urban areas" and "built-up settlement areas" (residential construction sites, mixeduse areas, industrial and commercial areas, and areas of a special functional character).

The location, size and distribution of open spaces (parks, cemeteries) and water surfaces are analysed within an urban settlement. Green spaces are ignored if not entirely free of buildings or transportation infrastructure. Regarding water surfaces, it was determined that all above-ground watercourses that did not run dry during the year were to be included in the investigation. The following minimum values were defined: 1 ha for the object types cemetery, park, camping site, golf course as well as for standing bodies of water; a minimum width of $>6 \mathrm{~m}$ for rivers and streams. All of these areas are classified as belonging to the group "green space and water bodies." The geometry of building footprints formed the base data to determine the ratio of built-up area to total area (coverage ratio) for every individual ATKIS polygon.

In order to calculate the "Euclidean distance", the polygon dataset was converted into raster data with a cell width of $100 \mathrm{~m} \times 100 \mathrm{~m}$. Each cell was given an attribute value corresponding to a form of use. In the case of several forms of use for one cell, the value was selected as the primary form of use.

The third variable, "affected population", is derived from the mapped "potential at-risk areas" together with the raster map of population data from the National Census of 2011 (Statistical Offices of the Federal Government and the Federal States, 2015). With a cell width of $100 \mathrm{~m} \times 100 \mathrm{~m}$, the raster data gives a population figure for every cell. The minimum value for the population in any cell is three (for reasons of data protection). Thus cells with only one person as well as cells with zero population or a population of two indicate a population of three.

The GIS-supported calculation of these three variables was broken down into five steps (Figure 1). 


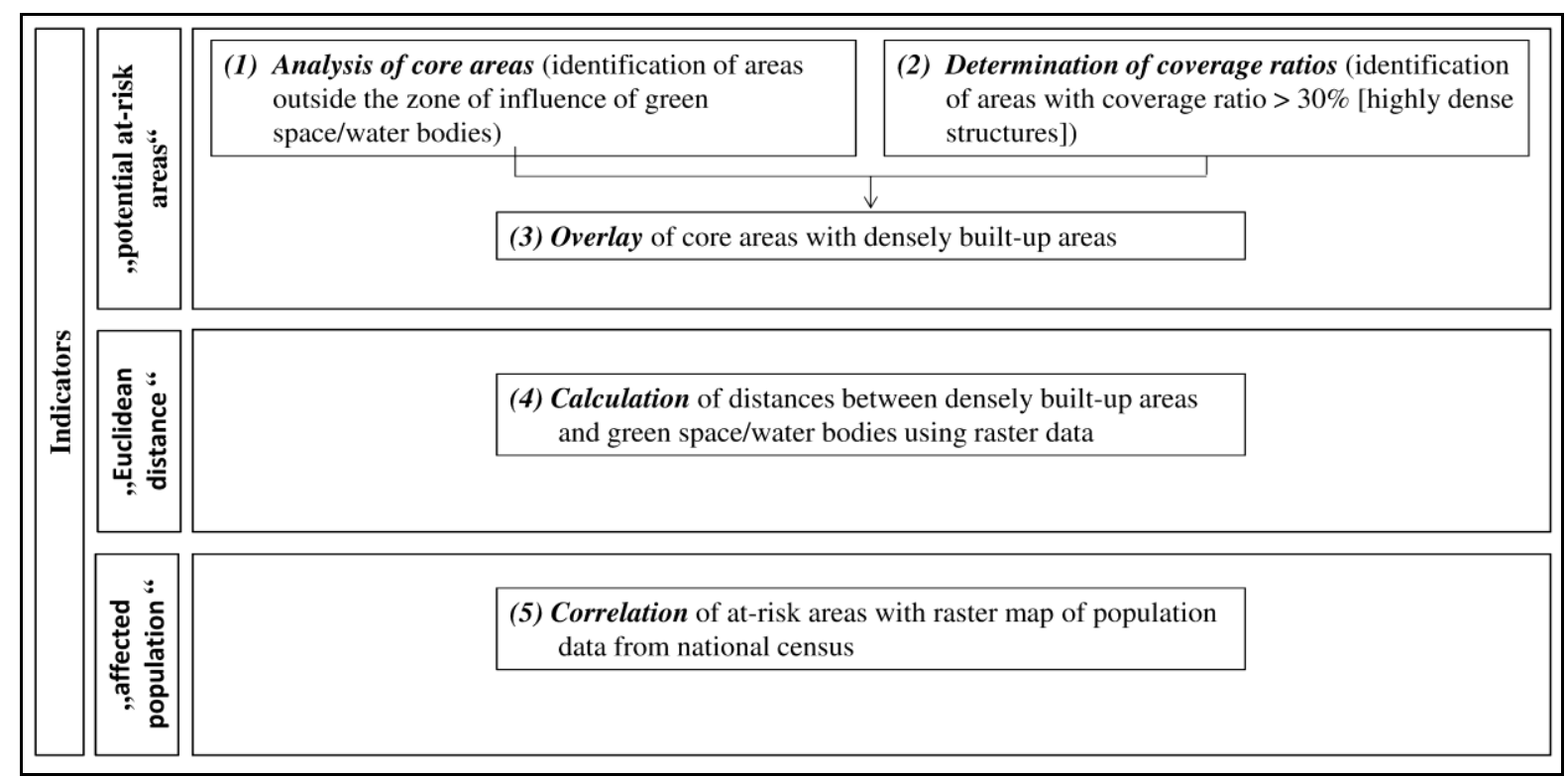

Figure 6: Overview of the process steps to calculate the specified variables (source: Authors).

\section{(1) Analysis of core areas}

The analysis of core areas is realised by creating a buffer around green spaces and bodies of water as well as a buffers extending from the surrounding open space into the urban settlement. The width of the buffer depends on the assumed border effects. In the case at hand, the buffer around public green spaces and water surfaces within the urban settlement as well as the outlying open spaces extended an average of $75 \mathrm{~m}$ from the outer perimeter. This figure of $75 \mathrm{~m}$ was chosen under the assumption that the microclimatic impact of green spaces and bodies of water generally extends out to the adjacent structures. This is supported by the findings of Taha et al. (1991) that a temperature lowering effect of green spaces can be detected at a distance equivalent to five times the height of the tree canopy. Here the height of trees in public parks is taken to be at least $15 \mathrm{~m}$, which corresponds to a zone of influence extending to $75 \mathrm{~m}$.

The parameter describes urban areas that are outside the zone of influence of public green spaces and bodies of water as well as surrounding open space.

\section{(2) Identification of polygons with a coverage ratio $>30 \%$}

Using the official data on building footprints, it is possible to determine the ratio of builtup land to total land area for every polygon. Here the focus is on residential areas with multifamily housing, mixed-use areas, industrial and commercial areas as well as areas of a special functional character. The aim is to pinpoint sites with a coverage ratio higher than $30 \%$. Such sites can be assumed to be densely built-up environments with a deficit of green space. Conversely, all built-up sites with a low coverage ratio can be assumed to possess sufficient capacity to develop green spaces with a positive microclimatic impact on the built environment. This assumption is backed up by our own field investigations as well as aerial photography assessment (cf. Heber \& Lehmann, 1993, 1996; Arlt \& Lehmann, 2007, 2008). It has been determined that built-up sites featuring residential usage (multi-family housing), mixed usage, industrial and commercial usage as well as usage of special functional character with a coverage ratio higher than $30 \%$ have a level of soil sealing between $54 \%$ and $93 \%$ (median value: $82 \%$ ) (Figure 2). 


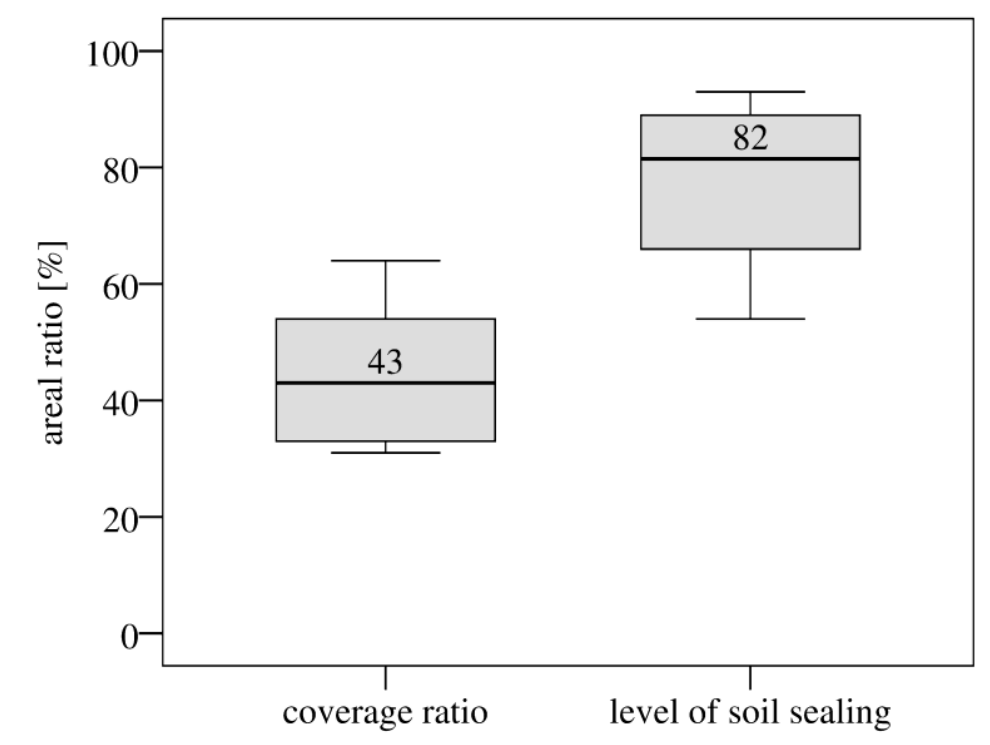

Figure 7: Built up sites with residential usage (multi-family housing), mixed usage, industrial and commercial usage as well as usage of special functional character - spread of values for coverage ratio and the related level of soil sealing (source: Authors).

Results take the form of areal ratios for the total urban settlement or built-up sites within the urban settlement as well as the pinpointing of high density structures.

(3) Overlay of core areas and high density structures (coverage ratio > 30\%)

The aim of this process step is to locate the "potential at-risk areas" in the urban settlement as well as to quantify their areal ratios. The findings from the analysis of core areas correlate with those of the analysis of high density structures to enable identification of areas in the urban settlement that lie outside green spaces and bodies of water (including the buffer zone of $75 \mathrm{~m}$ ) and which have a coverage ratio of more than $30 \%$.

(4) Calculation of distances between densely built-up areas and green space/water bodies using raster data

By calculating the Euclidean distance between densely built-up areas and green spaces or bodies of water it is possible identify and quantify the size of those areas that suffer from poor accessibility to green spaces on hot summer days.

The Euclidean distances are determined using the Esri-ArcGIS-Toolbox (proximity analysis) by examining all distances between the outer cells of densely built-up areas and green spaces/water bodies. Specifically, the Euclidean distance is measured from the centre of the target cells to the centre of the surrounding (green) cells. In the method presented the indicator "average Euclidean distance to green space in densely built-up settlement area" is calculated by considering all distances between the densely built-up areas and green spaces/bodies of water. The minimum distance corresponds to the cell width of $100 \mathrm{~m}$.

(5) Correlation of potential at-risk areas with the raster map of population data from the National Census 2011

The number of affected residents is calculated by examining the census data of raster cells for the pinpointed at-risk areas. For illustration purposes, the method was applied to the following seven structurally diverse German towns and cities: Aachen, Dresden, Halle, Krefeld, Landau, Neubrandenburg and Oldenburg (Oldb), whose populations range from 
40,000 to over 500,000 . Some have a strong industrial sector, whilst others are affected by rural environment.

\section{Results}

\section{Comparison on the basis of the investigated indicators}

The presentation of results for each indicator reflects the analytical steps described above.

\section{(1) Analysis of core areas}

Here all green spaces and water bodies in the settlement area are identified in order to calculate their areal ratio to the total area (Figure 3). Results show a ratio of green space and water bodies of approx. $4 \%$ to $16 \%$. The very low ratios of green space and water surfaces in Neubrandenburg and Landau are compensated by the large areas of open space making up $78 \%$ and $76 \%$ of total area respectively.

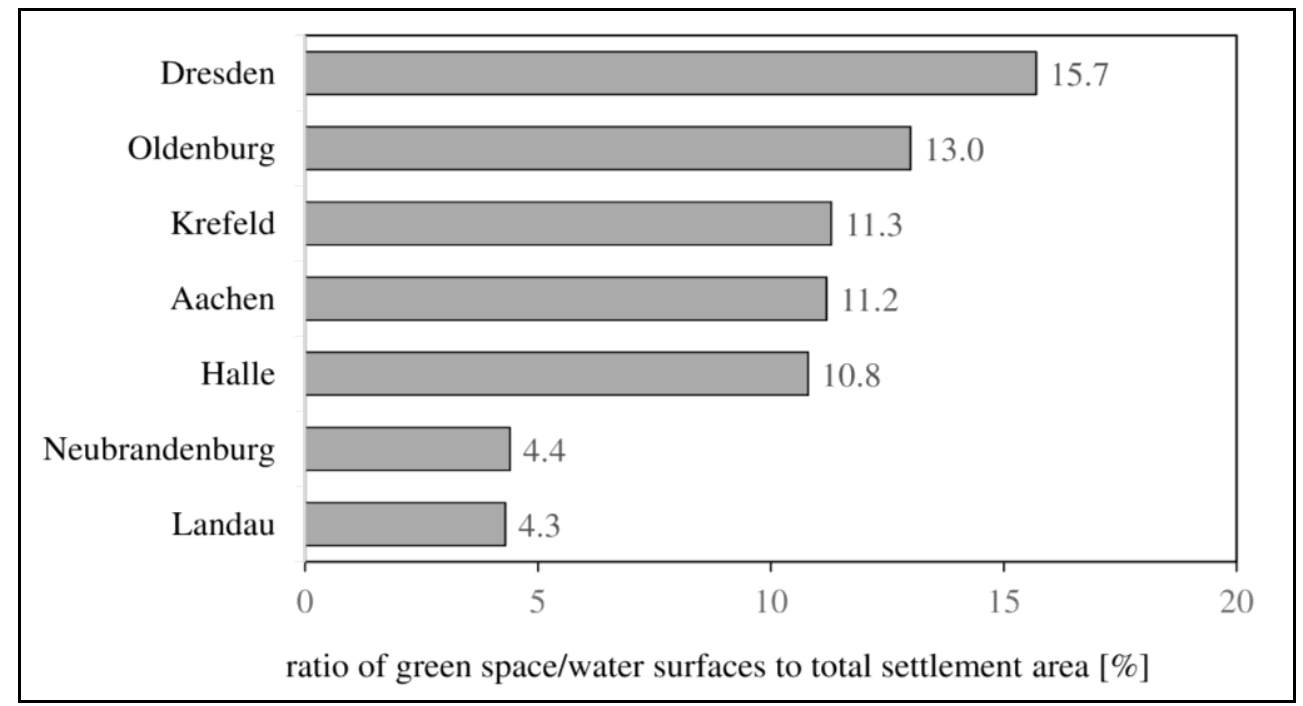

Figure 8: City comparison - ratio of green space/water bodies to total settlement area (source: Authors).

The size of the zone of influence of these areas is determined by the buffers extending outwards. Since it can be assumed that the open space surrounding the city will also have a positive effect on the microclimate, an additional buffer is posited as extending into built-up areas. The remaining areas (core areas) are sites that lie outside the zone of influence of green spaces and bodies of water as well as the outlying open space and which are thus at a microclimatic disadvantage (Figure 4). The range of values for such core areas is $44 \%$ to $55 \%$ of the total city area. However, it is difficult to determine the microclimatic situation in core areas on the basis of these results as such areas are highly diverse in their structural forms and correspondingly possess a variety of green inventory and structures. 


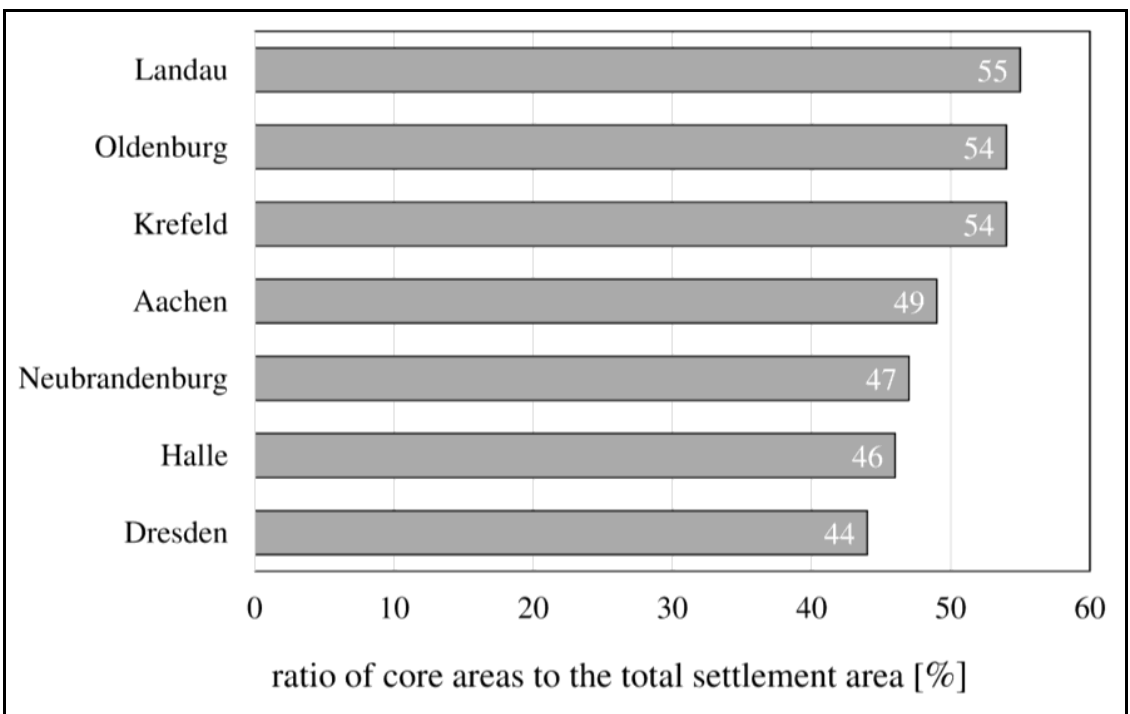

Figure 9: City comparison - ratio of core areas to the total settlement area (source: Authors).

(2) Identification of polygons with a coverage ratio $>30 \%$

Comparison of cities reveals considerable differences in their built-up structure. The builtup structure is understood to encompass all areas with a coverage ratio higher than $30 \%$ and where the forms of use encompass industrial and commercial sites, sites with a special functional character, residential and mixed-use sites with multi-family and multi-storey housing as well as open- and closed-perimeter blocks. The resulting indicator is the ratio of such areas to the total settlement area.

Whilst Oldenburg has a mere 5\% of such areas, Krefeld, Aachen and Landau have approx. $15 \%$ to $16 \%$. The figure for Dresden of approx. $7 \%$ can be explained by the fact that, following its almost complete destruction, the inner city was rebuilt with a much lower density of buildings. Thus the built-up areas of Dresden with a coverage ratio of more than $30 \%$ are generally highly developed residential areas preserved from before the Second World War as well as commercial areas developed in the 1990s (Figure 5).

(3) Overlay of core areas with the densely built-up structures (coverage ratio > 30\%)

By correlating core areas with densely built-up areas, it is possible to say that approx. $3 \%$ to $13 \%$ of built-up areas within the city precincts are areas in which local residents are at risk of heat stress on hot summer days (Table 1). It is not surprising that the city of Oldenburg, whose built-up areas are dominated by detached and semi-detached housing (approx. 85\% of buildings), should present the smallest ratio of potentially critical areas. Here the ratio of built-up sites with a coverage ratio of more than $30 \%$ is a mere $5 \%$ or so (Figure 5). By contrast, the ratio of built-up sites with a coverage ratio higher than $30 \%$ is approx. $16 \%$ in Krefeld (the maximum value), of which approx. $7 \%$ of built-up land has a high ratio of perimeter blocks (with some buildings in the inner courtyard, particularly in the city centre) as well as approx. $41 \%$ industrial and commercial areas. The situation in the city of Aachen is comparable. 


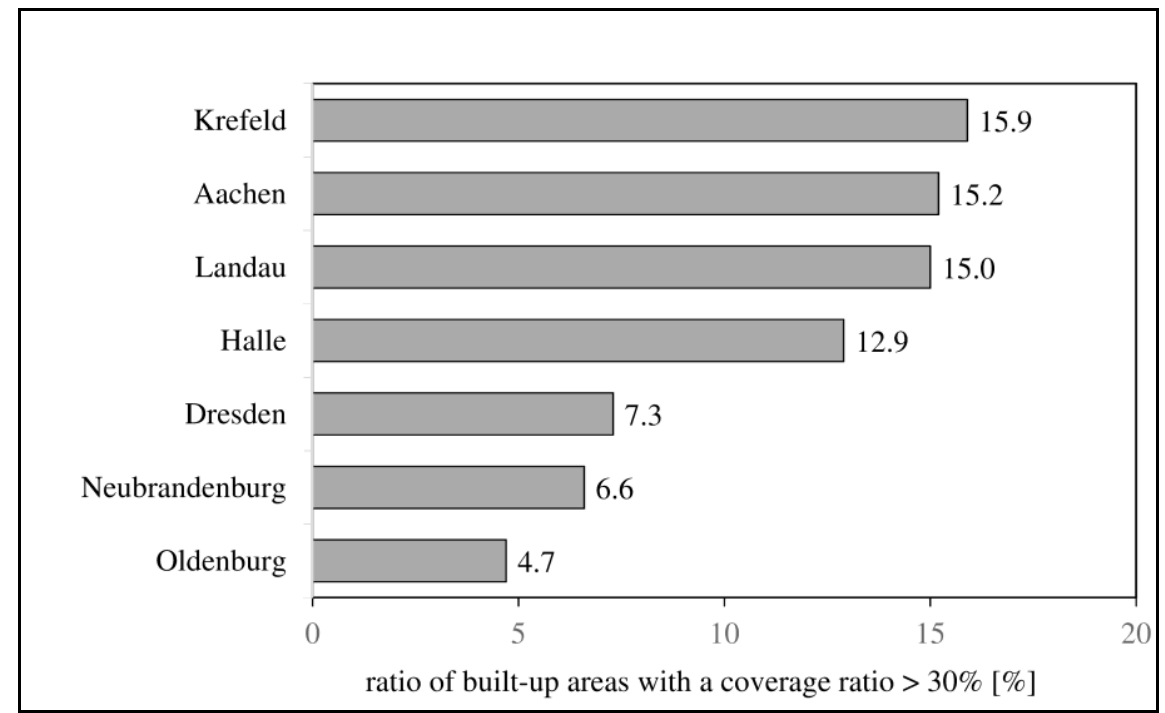

Figure 10: City comparison - ratio of built-up areas featuring multi-storey residential buildings, industrial and commercial sites as well as areas of special functional characters with a coverage ratio $>30 \%$ of the settlement area (source: Authors).

Table 1: City comparison - area ratios indicating the extent of potentially critical sites in the settlement area on hot summer days (heat islands).

\begin{tabular}{ll}
\hline City & $\begin{array}{l}\text { Ratio of at-risk areas } * \text { within } \\
\text { settlement area }[\%]\end{array}$
\end{tabular}

\begin{tabular}{ll}
\hline Aachen & 12.2 \\
Dresden & 4.7 \\
Halle & 8.8 \\
Krefeld & 12.8 \\
Landau & 11.0 \\
Neubrandenburg & 4.1 \\
Oldenburg & 3.2
\end{tabular}

* Potential at-risk areas: built-up sites featuring residential and mix-use buildings, industrial/commercial sites as well as sites with a special functional character with a coverage ratio $>30 \%$ and which are not adjacent to green spaces/water bodies or to outlying open space.

(source: Authors)

Comparing these results with the pro capita area of green space and water surfaces in settlement areas, close relationships can be observed. For cities with a high ratio of at-risk areas we also find an average to low pro capita inventory of green space and water surfaces. One striking exception is the town of Neubrandenburg, which shows the lowest proportion of green space and water surfaces and yet also has the smallest ratio of potentially at-risk areas (Figure 6). This finding reflects the town's structure, which is rather small and compact in its territorial extent: the ratio of the settlement area to the administrative area is a mere $22 \%$ or so (Figure 7). 


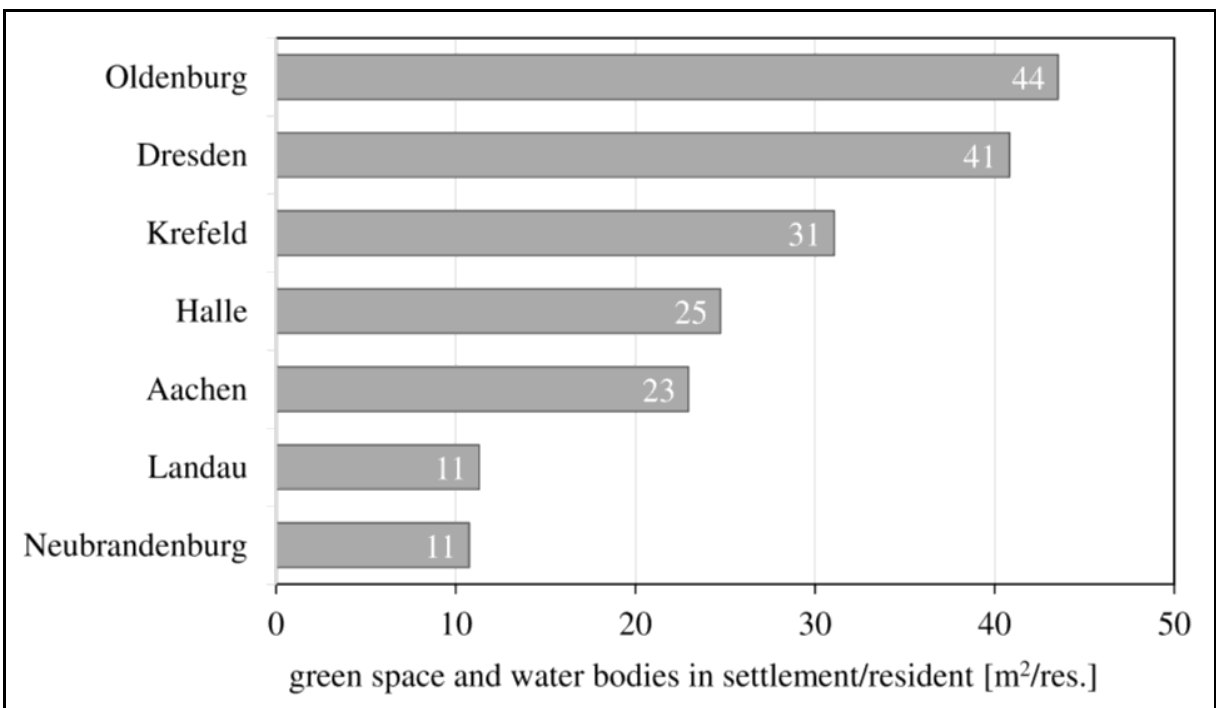

Figure 11: City comparison - pro capita area of green space and water surfaces (source: Authors).

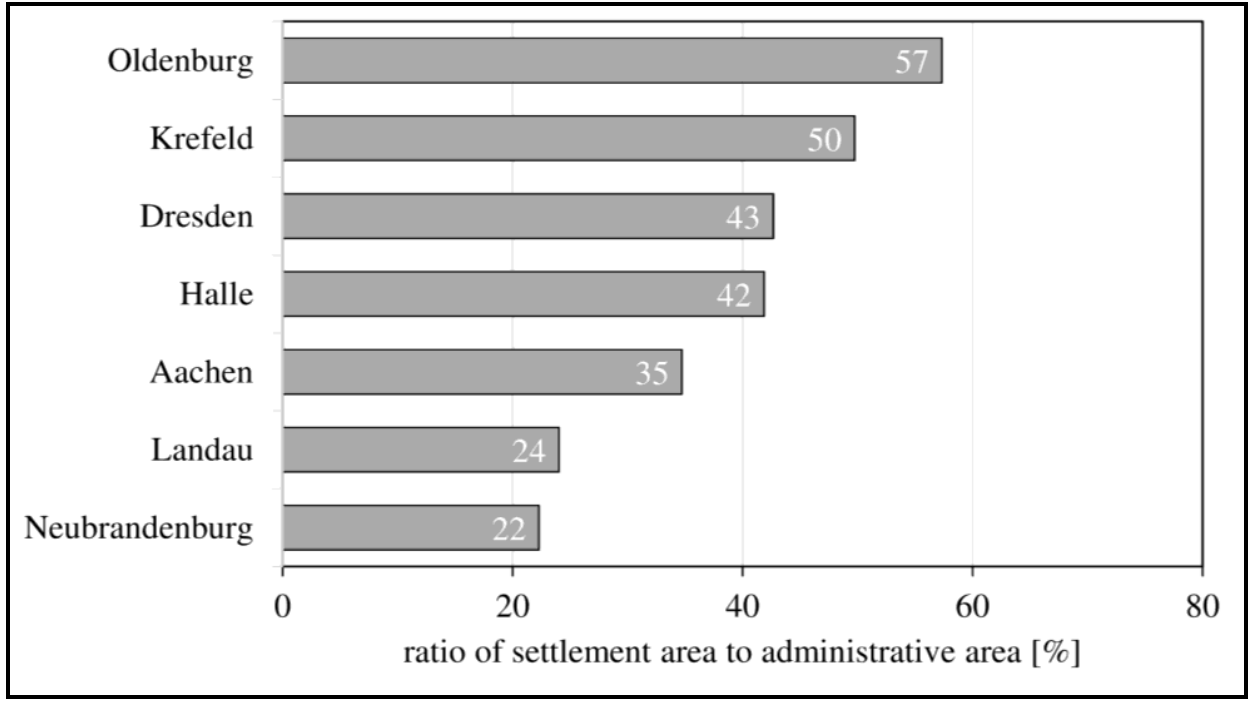

Figure 12: City comparison - ratio of settlement area to administrative area (source: Authors).

(4) Measuring the distance between densely built-up areas and green space/water bodies using raster data

Regarding the spatial proximity of densely built-up areas to recreational areas (public green space and water bodies as well as the margins of open spaces), we find an average Euclidean distance of 251 to $368 \mathrm{~m}$ and a maximum Euclidean distance of 539 to $943 \mathrm{~m}$ (Table 2). The large distances between densely built-up areas and recreational areas indicated for the city of Aachen can be partly explained by the high ratio of such densely built-up areas. Another cause is the wide spatial distribution of green spaces and bodies of water around these densely built-up areas. In contrast, the average Euclidean distance in the city of Dresden is $266 \mathrm{~m}$, a figure only marginally higher than in the town of Oldenburg (Table 2). Such results support the conclusion that the pattern of distribution of green spaces and water bodies in urban areas is a major factor in the prevalence of at-risk areas. 
Table 2: City comparison - distances (proximity values) characterising the accessibility of green spaces and bodies of water.

\begin{tabular}{lll}
\hline Town/city & $\begin{array}{l}\text { Average Euclidean distance to } \\
\text { green space in settlement area } \\
\text { (cell width }=\mathbf{1 0 0} \mathbf{~ m} \text { ) }[\mathbf{m}]\end{array}$ & $\begin{array}{l}\text { Maximum Euclidean distance to } \\
\text { green space in settlement area } \\
\text { (cell width }=\mathbf{1 0 0} \mathbf{~ m} \text { ) [m] }\end{array}$ \\
\hline Aachen & 368 & 943 \\
Dresden & 266 & 707 \\
Halle & 303 & 707 \\
Krefeld & 338 & 860 \\
Landau & 281 & 539 \\
Neubrandenburg & 254 & 632 \\
Oldenburg & 264 & 640 \\
\hline
\end{tabular}

(source: Authors)

(5) Correlation of potential at-risk areas with the raster map of population data from the National Census 2011

By correlating potential at-risk areas with population data from the national census it is possible to estimate the percentage of local residents who may be affected. Thus it can be seen that every fourth resident of the city of Aachen is living in a potential at-risk area (Figure 8). If we compare the data on the percentages of at-risk residents with the indicator "ratio of built-up areas with coverage ratio $>30 \%$ " then a dependency is apparent. With at-risk populations of $25 \%$ and $22 \%$ respectively, the cities of Aachen and Krefeld have a "ratio of built-up areas with coverage ratio $>30 \%$ " of approx. 15\% and 16\% (Figure 5). While the town of Landau displays the same value as Aachen for "ratio of built-up areas with coverage ratio $>30 \%$ " of $15 \%$, the much small ratio of "affected population" of $14 \%$ can be attributed either to a lower population density or to a higher proportion of industrial and commercial areas and/or areas of special functional character (Figure 8 and Figure 5)

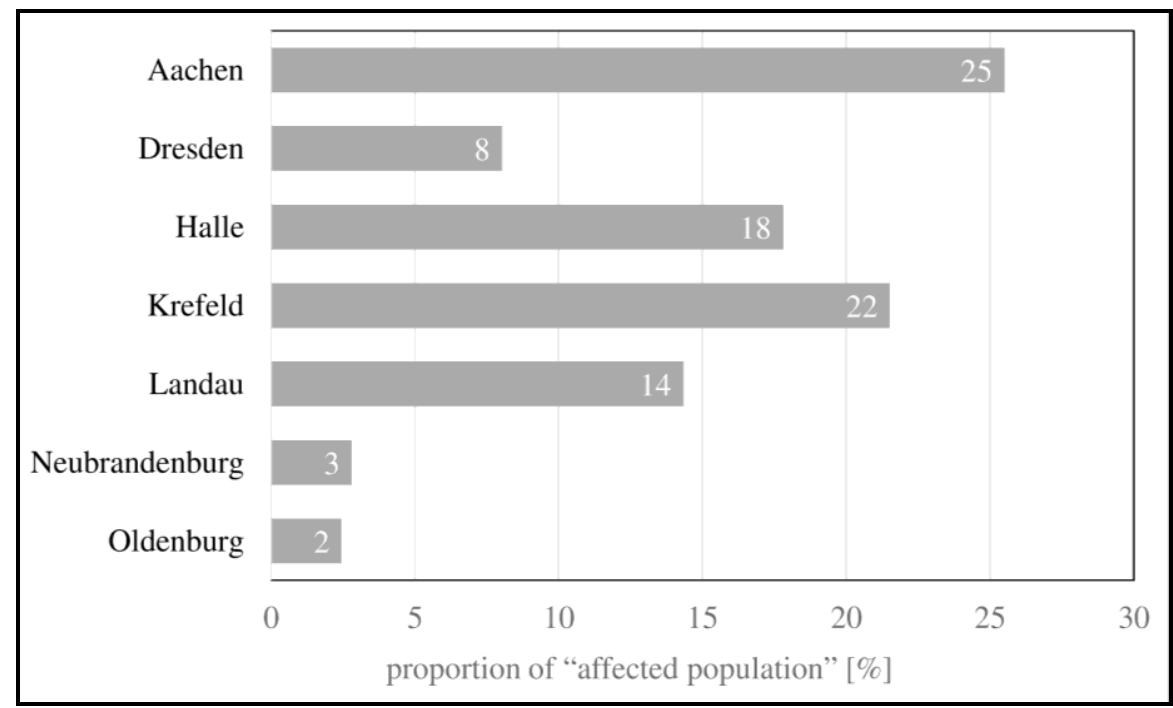

Figure 13: City comparison - ratios of "affected population" in the investigated towns (source: Authors).

\section{City comparison based on a range of criteria}

The cities are compared in terms of a range of criteria normalised for extreme values. This requires normalisation of the diverse variables to a uniform scale. Thus the city-based 
variables are converted to a scale between zero and one in which zero is the worst value and one the best.

In order to identify built-up areas in the settlement area at risk from adverse microclimatic conditions, the indicators "potential at-risk areas", the proximity measures "average Euclidean distance" and "maximum Euclidean distance" of densely built-up areas to green space and water bodies in the settlement area as well as to the surrounding open space and the ratio of "affected population" in the city were all considered in evaluation. Results show that, while none of the cities can be said to present optimal conditions, Dresden (the largest) can be positively rated in view of the number and good distribution of public green spaces and water bodies. Only Oldenburg and Neubrandenburg are ranked higher in terms of green space and water body provision (Figure 9). The normalised results provide a good summary of the previous research findings on the individual indicators.

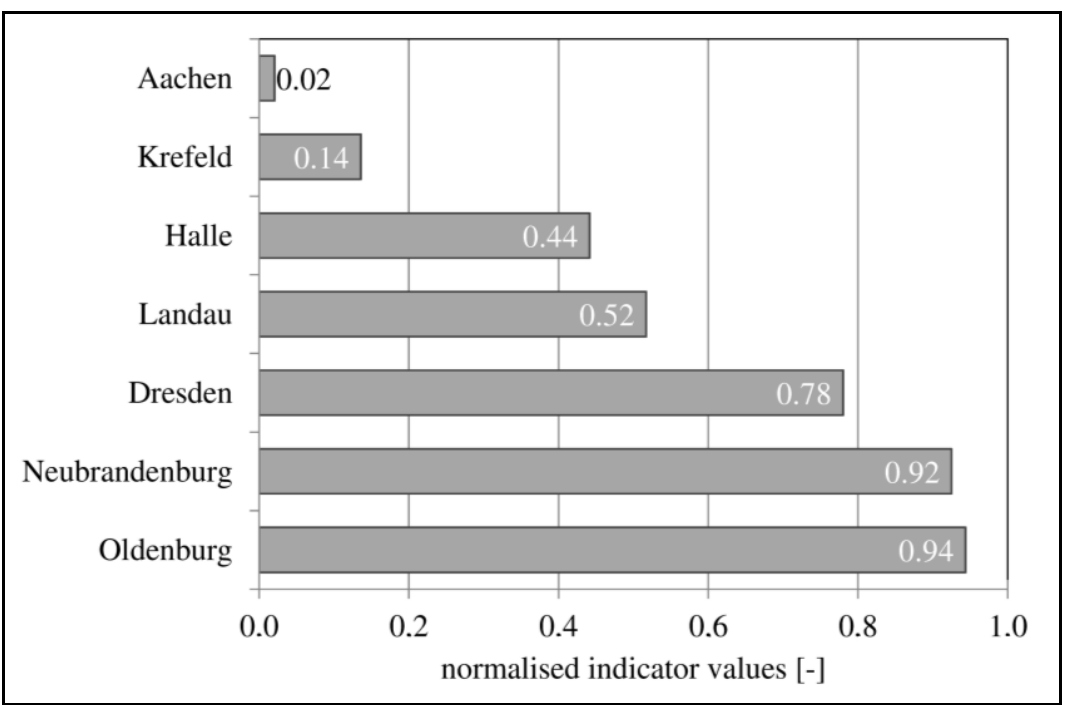

Figure 14: City comparison of the quality of urban green spaces and water bodies within the settlement area on the basis of a multi-factor assessment with normalisation of extreme values - the normalised indicator values are summed and then normalised a second time (Data source: (C) GeoBasis-DE / BKG 2009) (source: Authors).

\section{Conclusion and discussion}

The GIS-based method presented enables the microclimatic influence of public green spaces and watercourses/bodies in the settlement area as well as the influence of surrounding open space to be identified and quantified. In this way potentially critical areas in towns and cities can be pinpointed at a medium-scale level $(1: 25,000)$. The method investigates the physiognomy of cities and describes their physical characteristics by means of indicators and indices. It is possible to automate practically all stages of the analysis. This method is suitable for implementation as part of a nationwide monitoring system. While the IOER is planning to incorporate these results into the IOER MONITOR, ${ }^{8}$ the calculation of Euclidean distances currently require so much processing time that a nationwide application is not foreseen for the time being. The method was tested on seven highly disparate towns and cities in regard to territorial extent, population, location within Germany as well as historical development. Clear dependencies were uncovered between the urban structure and distribution/extent of green space, on the one hand, and microclimatic conditions. The comparison reveals a range of strengths and weaknesses. At the same time, potential was revealed to improve the urban climate. An evaluation of the towns and cities investigated showed a range of characteristics.

\footnotetext{
${ }^{8}$ www.ioer-monitor.de
} 
This diversity can be attributed in part to the different conceptions of a "good quality of urban life." This can be traced throughout the history of these cities and still holds true today. From our modern perspective we note clear differences to previous ages. Ways of life from the past can give rise to structures that are still influential today and which restrict contemporary ways of life.

If we focus solely on the microclimatic situation, then the town of Oldenburg presents the highest quality in comparison to the other towns and cities. One explanation is that Oldenburg has an above average proportion of detached homes and thus a low ratio of densely built-up areas, while simultaneously possessing a wealth of public green space. This shows how the consideration of only one aspect of a city quickly raises the questions of whether this corresponds to our conception of urban living and whether we wish our towns and cities to resemble Oldenburg. From our current perspective the answer has to be no. Rather, this single finding underlines the fact that the complex assessment of a city requires inclusion of a wide range of factors such as compactness, complexity, mobility, pollution, and structural diversity. Such detailed investigations must look at the specific mix of strengths and weakness in each individual city, a mix that is influenced by local framework conditions as well as wider societal factors. The complete findings of the research project will be published in late 2015. The authors can reveal here that the town of Oldenburg takes second last place in the complex evaluation of the towns and cities under study.

\section{References}

Alexandri, E. \& Jones, P. (2008) Temperature decreases in an urban canyon due to green walls and green roofs in diverse climates. Building and Environment, 43, pp. 480-493.

Arlt, G., Hennersdorf, J., Lehmann, I. \& Thinh, N. X. (2005) Auswirkungen städtischer Nutzungsstrukturen auf Grünflächen und Grünvolumen. Dresden, IÖR-Schriften 47.

Arlt, G. \& Lehmann, I. (2007) Ökologische Flächenleistungen. Typologische Untersuchungen von städtischen Wohn-, Misch- und Zentrumsgebieten. Stadt + Grün. 5(2007), pp. 36-40.

Arlt, G. \& Lehmann, I. (2008) Ökologische Flächenleistungen teilstädtischer Gebiete -

Fallstudien in Bonn und Dresden. In: Roch, I., Banse, J. \& Leimbrock, H. (eds.)

Freiraum- und Wohnqualitäten - Potenziale für den städtischen Umbau, pp. 259-279. Aachen, Shaker.

Bowler, D. E., Buyung-Ali, L., Knight, T. M. \& Pullin, A. S. (2010) Urban greening to cool towns and cities: A systematic review of the empirical evidence. Landscape and Urban Planning. 97 (3), pp. 147-155.

Endlicher, W., Jendritzky, G., Fischer, J. \& Redlich, J.-P. (2008) Heat waves, urban climate and human health. In: Marzluff, J. M., Shulenberger, E., Endlicher, W., Alberti, M., Bradley, G., Ryan, C. Simon, U. \& ZumBrunnen, C. (eds.): Urban ecology. An international perspective on the interaction between humans and nature, pp. 269-278. New York.

Finke, L. (1993) Stadtentwicklung unter ökologisch veränderten Rahmenbedingungen. Zukunft Stadt 2000. pp. 321-381.

Gill, S., Handley, J. F., Ennos, A. R. \& Pauleit, S. (2007) Adapting Cities for Climate Change: The Role of the Green Infrastructure. Built Environment, 33(1), pp. 115-133. DOI: $10.2148 /$ benv.33.1.115

Gill, S., Handley, J., Ennos, R. \& Nolan, P. (2009) Planning for Green Infrastructure: Adapting to Climate Change. In: Davoudi, S., Crawford, J. \& Mehmood, A. (eds.): Planning for Climate Change. Strategies for Mitigation and Adaptation for Spatial Planners, pp. 249-261. London.

Goldberg, V. \& Bernhofer, C. (2001) Quantifying the coupling degree between land surface and the atmospheric boundary layer with the coupled vegetation-atmosphere model 
HIRVAC. Annales Geophysicae, 19, pp. 581-587. DOI:10.5194/angeo-19-581-2001, 2001

Haase, D. (2001) Freiraum, Freiflächen und Natur in der Stadt des 21. Jahrhunderts Notwendigkeit oder Luxus? Berichte zur deutschen Landeskunde 75 (2/3), pp. 271-282.

Heber, B. \& Lehmann, I. (1993) Stadtstrukturelle Orientierungswerte für die Bodenversiegelung in Wohngebieten - Teilergebnis zum Forschungsprojekt "Stadtstrukturelle Orientierungswerte für die Bodenversiegelung - Naturnahe Regenwasserbewirtschaftung in Siedlungsgebieten". Dresden, IÖR-Schriften 05.

Heber, B. \& Lehmann, I. (1996) Beschreibung und Bewertung der Bodenversiegelung in Städten. Zweiter Beitrag zum Forschungsprojekt "Stadtstrukturelle Orientierungswerte für die Bodenversiegelung - Naturnahe Regenwasserbewirtschaftung in Siedlungsgebieten". IÖR-Schriften 05. Dresden.

Hege, H.-P., Lausterer, H., Scheffler, V. \& Schwarting, H. (1998/99) Verbesserung des Stadtklimas durch Grün - Wirkungen, Planung und Umsetzung. Seminarpapier im Rahmen der Veranstaltung Instrumente der ökologischen Planung, Stadtklima 21; Universität Kaiserslautern, Lehr- und Forschungsgebiet Ökologische Planung und UVP; Kaiserslautern.

Kuttler, W., Müller, N., Dütemeyer, D. \& Barlag, A.-B. (2012) Prognose- und Diagnoseanalysen zur Verbesserung des Stadtklimas Stadtklimatische Untersuchungen in Oberhausen und Simulationen verschiedener Minderungsstrategien zur Reduktion der thermischen Belastung im Hinblick auf den Klimawandel. Dynaklim. Publikation, Nr. 25/April 2012.

Lafortezza, R., Carrus, G., Sanesi, G. \& Davies, C. (2009) Benefits and well-being perceived by people visiting green spaces in periods of heat stress. Urban Forestry \& Urban Greening, 8 (2), doi - 10.1016/j.ufug.2009.02.003, pp. 97-108.

Lehmann, I., Mathey, J., Rößler, S., Bräuer, A. \& Goldberg, V. (2014) Urban vegetation structure types as a methodological approach for identifying ecosystem services Application to the analysis of micro-climatic effects. Ecological Indicators, 42, pp. 58-72. DOI:10.1016/j.ecolind.2014.02.036

Mathey, J., Rößler, S., Lehmann, I., Bräuer, A. \& Goldberg, V. (2011) Anpassung an den Klimawandel durch Stadtgrün - klimatische Ausgleichspotenziale städtischer Vegetationsstrukturen und planerische Aspekte. In: Böcker, R. (eds.) Die Natur im Wandel des Klimas. Eine Herausforderung für Ökologie und Planun, pp. 79-88. Darmstadt, Kompetenznetzwerk Stadtökologie (CONTUREC; 4).

Mathey, J., Rößler, S., Lehmann, I., Bräuer, A., Goldberg, V., Kurbjuhn, C., et al. (2011) Noch wärmer, noch trockener? Stadtnatur und Freiraumstrukturen im Klimawandel. Abschlussbericht zum F+E-Vorhaben "Noch wärmer, noch trockener? Stadtnatur und Freiraumstrukturen im Klimawandel". Bonn-Bad Godesberg, Münster BfN-Schr.-Vertrieb im Landwirtschaftsverl.

Matzarakis, A. (2001) Die thermische Komponente des Stadtklimas. Freiburg, Meteorologischen Institutes der Universitä Freiburgt.

Naturkapital Deutschland - TEEB DE (2012) Der Wert der Natur für Wirtschaft und Gesellschaft - Eine Einführung. München, Helmholtz-Zentrum für Umweltforschung (UFZ) Leipzig, Bundesamt für Naturschutz Bonn.

Nohl, W. (1993) Kommunales Grün in der ökologisch orientierten Stadterneuerung. IMUInstitut (ed.), Bd. Handbuch und Beispielsammlung. Studien, München 19.

Oke, T. R., Crowther, J. M., McNaughton, K. G., Monteith, J. L. \& Gardiner, B. (1989) The micrometeorology of the urban forest. Philosophical Transactions of the Royal Society of London. Series B, Biological Sciences, 324 (1223), pp. 335-349. 
Sukopp, H \& Wittig, R. (1998) Stadtökologie. Stuttgart, Jena, Lübeck, Ulm, Gustav Fischer Verlag.

Statistische Ämter des Bundes und der Länder (2015) Einwohnerzahl je Hektar. Ergebnisse des Zensus am 9. Mai 2011 pro ha. Wiesbaden, Statistisches Bundesamt.

Taha, H., Akbari, H. \& Rosenfeld, A. H. (1991) Heat island and oasis effects of vegetative canopies: Micro-meteorological field-measurements. Theoretical and Applied Climatology, 44(2), pp. 123-138. DOI: 10.1007/BF00867999

Wilmers, F. (1990) Effects of Vegetation on Urban Climate and Buildings. Energy and Buildings, 15/16, pp. 507-514. 